\title{
Hajari, Nisid \\ Midnight's Furies: \\ The Deadly Legacy of India's Partition
}

Oliver Stuenkel*

Massachusetts: Houghton Mifflin Harcourt, 2015. 328p.

Partition, the division of the Indian subcontinent into two countries in 1947, will always be remembered as one of the 20th century's major tragedies, involving one of the greatest forced human migrations in history, displacing more than 10 million people. It led to more than a million deaths in the context of Britain's departure from the subcontinent and the independence of India and Pakistan. Finally, it was the opening chapter of one of the world's most complex and unresolved rivalries, producing a nuclear hot spot many regard as the most dangerous in the world.

Nisid Hajari has written a very readable book about the politics of Partition, detailing the negotiations and power dynamics in the run-up to August 15, 1947. With journalistic skill, the author provides intimate portraits of the book's main characters, Jawaharlal Nehru and Mohammed Ali Jinnah. Gandhi, Vallabhbhai Patel (Sardar) and Lord Louis Mountbatten also appear frequently, but Hajari essentially depicts the drama of Partition as a two-man show.

While Hajari excels at transforming a complex and unwieldy event into a page-turner, his account is India-centric and ultimately too biased towards Nehru's views to provide a balanced account. India's first Prime Minister, the reader is told on the first pages of the book, was "dashing", "famously handsome", had "high, aristocratic cheekbones and eyes that were deep pools - irresistible to his many female admirers". "Although disdainful of superficialities, he took great care with his appearance", the author marvels. Throughout the book, Hajari describes Nehru's supposedly superhuman qualities, for example when he offers risking his life to protect Muslims in Old Delhi.

Jinnah, by contrast, is largely depicted as a power-hungry crook who lacked any principles, "irascible" and "criminally negligent" in his thinking

\footnotetext{
* Assistant Professor of International Relations, School of Social Sciences, Fundação Getulio Vargas (FGV). São Paulo, SP, Brazil. oliver.stuenkel@fgv.br
} 
about the human consequences of his demand for Pakistan. On the same page, the reader is told that Jinnah's "frigid demeanour was as legendary as Nehru's charm". Jinnah is also described as sleazy, lusting for a 16-year old girl when he was already in his 40s. Hajari does not explain how somebody can be irascible, sleazy and frigid at the same time.

Nehru, the author concedes, had flaws as well. As Hajari writes, Nehru refused to accept the Muslim League as a coalition partner in 1937, except on humiliating terms that included the unconditional merger of Muslim League parliamentary parties into the Congress. Nehru's arrogant and aloof behavior was precisely what Jinnah needed to strengthen anxieties that Muslims had regarding a Hindu majority-dominated India. And yet, the book leaves little doubt about who is the villain of the story.

What is perhaps most problematic with this account is that the idea of creating Pakistan is described as little more than a ploy used by Jinnah to get his political career back on track after the return of Gandhi from South Africa and the rise of the Hindu-dominated Congress pushed him to the sidelines. After his young wife commits suicide, Jinnah moves into a somber house with his evil sister Fatima. While Nehru is driven by high ideals, the book suggests, Jinnah is moved by bitterness and the desire for revenge.

Yet the idea of Pakistan was far more than a mere bargaining chip invented by Jinnah. Hajari remains silent on key figures such as Muhammad Iqbal, one of the most important figures in Urdu literature and the philosopher who inspired the Pakistan Movement. The author seems to suggest it would have merely taken a more moderate representative of the Muslim League to avoid Partition.

Yet this argument overlooks that the British-supervised elections in 1937 and 1946, which the Hindu-dominated Congress won easily, only hardened Muslim identity, and made partition inevitable. The British policy of defining communities based on religious identity, which fundamentally altered Indian self-perceptions, requires far more attention to explain the dynamics that led to Partition. Churchill, in particular, saw consolidating a Muslim identity in India and stoking sectarian tensions as essential to prolonging British rule on the subcontinent (he actively supported Jinnah's cause in the years before 1947).

Hajari recognizes that Mountbatten's decision to anticipate Britain's withdrawal and let an unprepared mapmaker draw the borders within 40 days (without visiting the regions affected, as the author correctly notes) turned the whole project far more deadly than it could have been under other 
circumstances. Jinnah hardly could have anticipated such irresponsible behavior by the British.

As Pankaj Mishra (2007) writes,

No one had prepared for a massive transfer of population. Even as armed militias roamed the countryside, looking for people to kidnap, rape, and kill, houses to loot, and trains to derail and burn, the only force capable of restoring order, the British Indian Army, was itself being divided along religious lines - Muslim soldiers to Pakistan, Hindus to India. Soon, many of the communalized soldiers would join their co-religionists in killing sprees, giving the violence of partition its genocidal cast ... British soldiers confined to their barracks, ordered by Mountbatten to save only British lives, may prove to be the most enduring image of imperial retreat.

Midnight's Furies does not uncover many new sources and specialists will find nothing that will change their views, but the book is well-researched overall. One somewhat strange exception is Rashtriya Swayamsevak Sangh (RSS), a right wing Hindu organization, which Hajari wrongly abbreviates as RSSS throughout the book.

Despite its bias, the book thus points to the importance of a crucial historical turning point that continues to shape current geopolitical debates. As the discipline of International Relations in particular continues to overly focus on what happened in Europe after World War II, many more books on the war's aftermath in Asia and elsewhere in the world are needed.

\section{REFERENCE}

MISHRA, Pankaj. Exit Wounds: The legacy of Indian partition. 13 Aug., 2007. Available at: http://www.newyorker.com/magazine/2007/08/13/exit-wounds; Accessed on: 12 jan. 2016.

Resenha recebida em 2 de fevereiro de 2016. Aprovada em 13 de fevereiro de 2016. 